\title{
Identification of Equine Heat Shock Proteins Gene and Their mRNA Expression Analysis after Exercise
}

\author{
Hyun-Woo Cho ${ }^{1}$, Jeong-Woong Park ${ }^{1}$, Jae-Young Choi ${ }^{1}$, Sivakumar $\mathrm{S}^{2}$, Nam-Young Kim ${ }^{3}$, Teak-Soon \\ $\mathrm{Shin}^{1}$, Seong-Keun Cho ${ }^{1}$, Byeong-Woo Kim ${ }^{1}$ and Byung-Wook Cho ${ }^{1 *}$

\begin{abstract}
${ }^{1}$ Department of Animal Science, College of Life Sciences, Pusan National University, Miryang 627-702, Korea
${ }^{2}$ Department of Bioenvironmental Energy, College of Natural Resource and Life Science, Pusan National University, Miryang 627-706, Korea

${ }^{3}$ Subtropical Animal Experiment Station, National Institute of Animal Science, RDA, Jju 690-150, Korea
\end{abstract}

Received October 1, 2013 /Revised January 17, 2014 /Accepted February 7, 2014

\begin{abstract}
The purpose of this study was to characterize equine heat-shock protein (Hsp) genes and analyze their expression pattern in various horse tissues and blood leukocytes after exercise. In a previous study, RNA sequencing of blood and skeletal muscles of thoroughbreds before and after exercise was performed using differently expressed gene (DEG) analysis. Three Hsp genes (HspH1, Hsp90a and Hsp70) were selected by DEG analysis and were found to be differentially expressed in either blood or muscle. To validate and extend previous observations on these genes, we performed RT-PCR analyses of horse tissue as well as real-time qPCR analyses of blood leukocytes after exercise. mRNA expression of these Hsp genes was found to be ubiquitous in the analyzed tissues (including thyroid, colon, skeletal muscle, cecum, kidney, spinal cord, heart, and lung). In addition, Hsp mRNA expression of these genes in extracted whole blood increased after 120 minutes of exercise compared to the baseline condition. These results are in agreement with the results of human and other experimental animals, suggesting that regulatory mechanisms that are responsible for upregulation of Hsp gene transcription may be conserved among species. Further investigations to correlate Hsp gene expression patterns with athletic performance or recovery processes after exercise are warranted.
\end{abstract}

Key words : Equus caballus, exercise, heat shock protein, real-time quantitative PCR, thoroughbred

\section{서 론}

세포는 주위 환경으로부터 스트레스를 받을 경우 그 세포가 가지고 있었던 본래의 기능을 유지하지 못한다. 그러나 스트 레스 단백질(stress protein)라고 불리는 몇몇 단백질들은 해당 세포가 스트레스에 노출되었을 때 그 본연의 기능을 유지하기 위하여 발현된다. 환경에 의한 가장 일반적인 스트레스는 온 도의 변화이다. 한 개체의 적정 생체 온도 이하일 경우 저온 충격이 가해지며, 이상일 경우 열 충격이 가해져 스트레스의 원인으로 작용한다고 알려져 있다. 열충격에 의해 발현이 증 가하는 유전자들의 존재는 초파리(Drosophila melanogaster)에 서 처음으로 관찰되었다. 초파리의 정상적인 체온 이상으로 열 충격을 가했을 때 발현이 증가하는 유전자들을 열충격 단 백질(heat shock protein, Hsp)이라고 명명하였다[29]. 열충격 단빽질들은 열 충격뿐만 아니라 다양한 스트레스 요인(산화적

\section{${ }^{*}$ Corresponding author}

Tel : +82-55-350-5515, Fax : +82-55-350-5519

E-mail : bwcho@pusan.ac.kr

This is an Open-Access article distributed under the terms of the Creative Commons Attribution Non-Commercial License (http://creativecommons.org/licenses/by-nc/3.0) which permits unrestricted non-commercial use, distribution, and reproduction in any medium, provided the original work is properly cited
요인, 저산소 상태, 포도당 또는 ATP 결핍, 국소빈혈 등)에 의해서도 발현이 증가한다 $[4,6,19]$. 열충격 단백질들의 기능 이 살아있는 세포의 항상성을 유지하는데 중요한 역할을 하 며, 이에 따라 열충격 단백질의 다양한 질환에서의 중요성이 알려지면서 임상에 적용되기 시작하였다[24].

스트레스가 없는 상태에서도 열충격 단백질은 분자 샤페론 으로 작용하여 단백질의 합성을 돕고 접힘과 조립 및 개체 발생 등을 돕는다[11, 14, 25]. 세포 내에서 중요한 역할을 담당 하기 때문에 열충격 단백질은 다양한 종 및 세포에서 유전자 구조와 조절 메커니즘 그리고 세포 내 기능이 매우 잘 보존되 어 있다고 알려져 있다[15].

운동이라는 생리학적인 요인이 열충격 단백질 유전자들의 발현을 유도할 수 있다는 연구가 보고되면서[10], 열충격 단백 질과 운동과의 연관성에 대한 연구가 수행되어 왔다. 이처럼 동에 따른 신체의 생리적 상태가 변함에 따라 다양한 조직에 존재하는 세포들의 유전자 발현이 변하게 된다. 스피드와 강 건성, 민첩성 등이 경제형질인 경주마의 경우 운동에 관한 연 구가 중요하지만 그 중요성에 비해 연구가 많이 되어있지 않 은 상태이다.

본 연구팀은 경주마(thoroughbred) 6 두의 운동 전, 후 골격 근과 혈액에서 RNA를 추출하여 RNA-sequencing을 선행적 으로 수행하였다. 전장 전사체 분석을 통하여 차등 발현하는 
유전자(Differentially Expressed Gene, DEG)를 얻었다. 흥미 롭게도 $\mathrm{DEG}$ 분석 데이터에서 열충격 단백질 중 $\mathrm{HspH}$ 과 $H s p 70$ 유전자의 발현이 운동 후에 증가됨을 확인할 수 있었다 [27].

Hsp70 family는 세포가 스트레스에 노출되었을 때 가장 많 이 발현되는 유전자들이다. 따라서 $H s p 70$ 유전자는 열 충격 분야에서 가장 광범위하게 연구되어 왔다. Hsp70 family는 분 자량이 약 $70 \mathrm{kDa}$ 이며 진핵생물의 $H s p 70, H s c 70, \operatorname{Bip} / \mathrm{Grp} 78$, $\mathrm{mtHsp70}$ 또는 원핵생물의 $\mathrm{DnaK}, H s c 66, H s c 62$ 등이 포함된다. Hsp70 family 중 가장 활발히 연구되어 온 두 가지 유전자는 $H_{s p} 70$ 과 $H_{s c 73}$ 이다. $H_{s c 73}$ (heat shock cognate $73 \mathrm{kDa}$ protein)은 분자량 $73 \mathrm{kDa}$ 의 단백질로 대부분의 세포에서 발현되 며, 발현의 유도성이 매우 낮다[34]. 스트레스가 없는 정상적인 상태에서는 지속적으로 발현되어 세포질에 존재하며, 스트레 스가 가해지는 동안 핵과 인으로 이동한다[38]. 이와는 반대로 $H s p 70$ 의 경우 정상적인 상태에서는 발현이 적다가, 스트레스 에 의해서 발현이 유도된다[35]. Hsp70은 스트레스에 반응하 여 세포질에서 급속히 합성된다. 세포질의 $H s p 70$ 은 단백질 합 성의 초기 단계에 관여한다고 알려져 있다[3]. $H s p 70$ 은 부분적 으로 합성된 펩타이드 서열에 결합함으로써, 뭉치거나 기능을 못하는 상태를 막는다. 단백질이 완전히 합성되면 $H s p 70$ 은 떨 어져 나가게 되고, 기능을 하는 3 차 구조로 접히게 된다. 추가 적인 변형과정을 거치기 위하여 $\mathrm{Hsp} 70 / \mathrm{Hsp} 90$ organizing protein에 의해 Hsp70과 Hsp90과 결합할 수도 있다[37]. 이러 한 기능 외에도 $H s p 70$ 은 단백질이 부분적으로 접힌 상태로 이동하는 것을 돕거나, 고온이나 산화적 스트레스가 왔을 때 변성된 단백질의 재접힘을 도움으로써 세포를 보호하기도 한 다. 추가로 직접적으로 세포사멸을 억제한다는 연구결과도 있 다[2].

Hsp90 family는 Hsp90a와 Hsp90ß, Grp94 (glucose regulated protein) 세 가지의 단백질로 이루어져 있다. $H s p 90$ 은 세포질과 핵, 소포체에 존재하며 다양한 종류의 세포에 존재 한다고 알려져 있다. Hsp70과 유사한 기능을 하며 다양한 스트 레스 요인들로부터 세포를 방어하는 역할을 담당한다. 또한 $H s p 90$ 은 에스트로겐(estrogen), 프로게스테론(progesterone), 글루코르티코이드(glucocorticoid), 안드로겐(androgen) 등 스 테로이드 호르몬이 없을 때 스테로이드 호르몬 수용체와 결합 하여 수용체를 불활성화 시킨다[30]. 호르몬이 존재할 때는 $H s p 900$ 떨어져 나감으로써 호르몬이 수용체에 결합할 수 있 게 되고, 호르몬-수용체 복합체는 특정 유전자들의 발현을 조 절한다.

$H s p H 1$ (heat shock $105 \mathrm{kDa} / 110 \mathrm{kDa}$ protein 1)은 고분자 량 $\mathrm{Hsp}$ 에 속한다. Hsp70과 Hsp90과 마찬가지로 다양한 스트 레스에 반응하여 발현이 유도된다. 마우스의 배 발생 과정에 서 일시적으로 발현이 증가하여 배 발달에 중요한 역할을 수 행할 것으로 예상된다[12]. $H s p H 1$ 은 스트레스의 유무와 상관
없이 $\mathrm{Hsc70/Hsp70과} \mathrm{복합체를} \mathrm{이루며} \mathrm{존재하여} \mathrm{Hsp70} \mathrm{fam-}$ ily와 기능적으로 연관이 있을 것으로 예상된다[13].

이와 같이 각종 스트레스를 제어하는데 중요한 역할을 하는 열충격 단백질 유전자에 대한 분자적 구명 및 경주마에 있어 서 가장 중요한 스트레스 요인인 운동 후 스트레스 제어와 관련된 연구는 전무하다.

따라서 본 연구는 말 열충격 단백질들의 분자적 구조를 구 명하기 위해 각종 조직에서의 발현 양상을 분석하였다. 또한 운동 후, 열충격 단백질유전자 발현 양상을 분석하였다. 본 연구에서 얻어진 결과들은 향후 말의 운동생리분야와 운동에 의한 스트레스 제어 기술 개발에 기초로 이용될 수 있을 것으 로 사료된다.

\section{재료 및 방법}

\section{연구대상의 선택}

공시재료는 RNA-sequencing을 통한 차등발현유전자 데이 터로부터 뽑은 열충격 유전자들의 말 조직별 발현여부를 확인 하기 위해 농촌진흥청 난지농업연구소의 더러브렛과 제주마 의 교배종인 제주산마 3 두의 갑상선, 결장, 골격근, 맹장, 신 장, 심장, 척수, 폐를 대상으로 하였다. 운동시간에 따른 혈액 내 열충격 유전자 mRNA의 발현관계를 확인하기 위해 함안 경주마 휴양조련시설의 더러브렛 2 두를 대상으로 하였다.

\section{대상 유전자의 선택}

본 실험을 진행하기 앞서 더러브렛 6 두의 운동 전, 후 근육 과 혈액에서 total RNA를 분리하여 cDNA를 합성한 후, Illumina sequencing 을 이용하여 RNA-seqeuncing을 수행하 였다. 도출된 raw data를 이용하여 차등발현분석을 수행하였 고, 열충격에 반응하여 발현이 증가된다고 알려진 Heat shock protein family에 속하는 HspH1, Hsp90a, Hsp70 유전자를 선 택하였다(Table 1).

\section{시료채취}

더러브렛 2 두를 treadmill에서 속보 운동을 시켜 운동 전, 운동 30 분 후, 60 분 후, 90 분 후, 120 분 후에 경정맥에서 $3 \mathrm{ml}$ 의 전혈을 추출하였다. $9 \mathrm{ml}$ 의 red blood cell (RBC) lysis buffer (Solgent, Daejeon, Korea)와 혼합한 후 vortexing하여 적혈구를 파괴하였다. $1,000 \mathrm{rpm}$ 에서 10 분 동안 원심분리한 후, 상층액을 버리고 white blood cell (WBC) pellet만을 모아 추가 실험을 위해 $-196^{\circ} \mathrm{C}$ 의 액체질소에 보관하였다.

아울러 제주산마 3 두의 8 개 부위(갑상선, 결장, 골격근, 맹장, 신장, 심장, 척수, 폐)의 조직은 도축 과정 중, 방혈 후 이분도체하여 각 조직별로 분류작업 시에 추출하였다. 
Table 1. Transcript ID, symbol and gene description in muscle and blood cells

\begin{tabular}{cllcc}
\hline Transcript ID & Symbol & \multicolumn{1}{c}{ Gene description } & Muscle & Blood \\
\hline ENSECAT00000020163 & HspH1 & Heat shock 105 kDa/110 kDa protein 1 & 3.54 & 1.81 \\
ENSECAT00000001035 & Hsp70 & Heat shock protein 72 kDa protein & 1.96 & - \\
ENSECAT00000020420 & Hsp90a & Heat shock protein 90 alpha & - & - \\
\hline
\end{tabular}

* Data are average fold change value of six thoroughbred horses

** Data were adapted and modified from Park et al. (2012).

\section{Total RNA 추출}

더러브렛에서 추출한 혈액의 얼어있는 WBC pellet을 $1 \mathrm{ml}$ 의 Trizol (Invitrogen, Karlsruhe, Germany)을 이용하여 pipetting 하여 cell을 풀었다. 풀어진 $\mathrm{WBC}$ 를 $1.5 \mathrm{ml}$ tube에 옮긴 후 ice에 10 분간 반응시켰다. 제주산마 조직들은 $50 ~ 100 \mathrm{mg}$ 을 뗴어내어 막자사발에서 액체질소 존재하에 막자로 잘게 갈았다. 갈려진 조직들은 $1.5 \mathrm{ml}$ tube에 넣은 후 ice에서 10 분간 Trizol과 반응시켰다. 그 후, 수층과 유기용매층으로 분리 시키기 위해 $200 \mathrm{ul}$ 의 chloroform을 분주하여 5 분간 반응시켰 다. 원심분리하여 total RNA가 들어있는 상층액을 $500 \mathrm{ul}$ 의 Isopropanol이 들어있는 새 tube에 옮긴 후 inverting 하였다. 원심분리하여 total RNA pellet을 down 시킨 후, $1 \mathrm{ml}$ 의 $75 \%$ $\mathrm{EtOH}$ 을 처리하여 상온에서 건조시켰다. 추출된 RNA는 20 ul의 RNase-free water에 희석하였다. 모든 과정은 $4^{\circ} \mathrm{C}$ 에서 진행되었다. genomic DNA의 오염을 막기 위해 RNase-free DNase kit (Qiagen)를 사용하였다. RNA의 상태를 확인하기 위해 전기영동하여 UV 상에서 $\mathrm{rRNA}$ 밴드 양상을 관찰하였 고, Spectrophotometer (NanoDrop® ND-1000)를 사용하여 농도와 순도를 확인하였다.

\section{CDNA 합성}

cDNA 합성을 위해 $3 \mathrm{ug}$ 의 total RNA가 사용되었고, MMLV (Moloney-Murine Leukemia Virus) reverse transcriptase (Promega, Madison, USA) 1 ul, Oligo-dT (Invitrogen) 1 ul, RNasin ${ }^{\circledR}$ ribonuclease inhibitor (Promega, Madison, USA) $1 \mathrm{ul}$, RNase-free water를 사용하여 cDNA를 합성하였 다. 합성하고 남은 total RNAs는 $-79^{\circ} \mathrm{C}$ 에 냉동 보관하였고, $\mathrm{cDNA}$ 는 추가 실험을 위하여 $4^{\circ} \mathrm{C}$ 냉장보관 하였다.

\section{Primer design}

원하는 유전자를 증폭하기 위하여 PRIMER3 software를 사 용하여 primer를 design하였다(Table 2). 서열정보는 NCBI와 Ensembl database를 참고하였다. $H s p 70$ 유전자의 primer는 논문[39]을 참고하여 사용하였다.

\section{RT-PCR}

cDNA상의 타겟 유전자를 증폭시키기 위하여 $100 \mathrm{ng} / \mathrm{ul}$ 로 희석한 cDNA $1 \mathrm{ul}, 5 \mathrm{pmol} / \mathrm{ul}$ 로 희석한 forward primer와 reverse primer를 각각 $1 \mathrm{ul}$ 씩, dNTP $3 \mathrm{ul}, 10 \mathrm{X}$ buffer $2 \mathrm{ul}$, HS-Taq (GENET BIO) 0.2 ul, D.W 11.8 ul를 넣어 총 20 ul로 $\mathrm{PCR}$ 을 수행하였다. $\mathrm{PCR}$ 의 조건은 다음과 같다. 첫 단계에서 $94^{\circ} \mathrm{C}$ 로 10 분간 denaturation을 시킨 후, $94^{\circ} \mathrm{C}$ 에서 20 초간 denaturation과 $60^{\circ} \mathrm{C}$ 에서 20 초간 annealing, $72^{\circ} \mathrm{C}$ 에서 40 초간 extension을 35 cycle 반복하였고 마지막 단계로 $72^{\circ} \mathrm{C}$ 에서 10 분간 extension하였다. 대조군으로 $G A P D H$ 를 사용하였고 $2 \%$ 의 Seakem LE agarose gel (Lonza, Rockland, USA)로 UV 상에서 band를 확인하였다.

\section{Real time qPCR 분석}

타겟 유전자의 상대적인 발현량을 측정하기 위하여 $\mathrm{C} 1000^{T M}$ Thermal Cycler (Bio Rad, Hercules, CA)를 이용하여 real-time qPCR을 수행하였다. 총 반응액은 $25 \mathrm{ul}$ 를 사용하였 고 용액의 구성은 다음과 같다. $14 \mathrm{ul}$ 의 SYBR green master mix (Bio Rad), $5 \mathrm{pmol} / \mathrm{ul}$ 로 희석된 forward primer와 reverse primer를 각각 $2 \mathrm{ul}, 5 \mathrm{ul}$ 의 distilled water, $50 \mathrm{ng} / \mathrm{ul}$ 로 희석된 cDNA 2 ul를 넣었다. real-time $\mathrm{qPCR}$ 의 조건은 다음과 같다. 먼저 $94^{\circ} \mathrm{C}$ 에서 10 분간 denaturation 시킨 후, $94^{\circ} \mathrm{C}$ 에서 10 초,

Table 2. Primers used for RT-PCR and real-time qPCR

\begin{tabular}{lllrr}
\hline GENBANK ID & Fragments & Primer's sequence $\left(5^{\prime}-3^{\prime}\right)$ & Product size $(\mathrm{bp})$ & Tm $\left({ }^{\circ} \mathrm{C}\right)$ \\
\hline NM_001493517.1 & Horse_HspH1_F & GTCTTTTGGAGGGGGAAAAA & 82 & 55.3 \\
NM_001493517.1 & Horse_HspH1_R & ACCTTGGCAGGAACAAACAC & & 57.3 \\
NM_001163955.1 & Horse_Hsp90a_F & AAGGAGCTGCACATCAACCT & 184 & 59.9 \\
NM_001163955.1 & Horse_Hsp90a_R & ACTGGCCGATCATGGAGATA & & 60.5 \\
NM_001256923.1 & Horse_Hsp70_F & CGTACGCGTTCAACATGAAG & 103 & 57.3 \\
NM_001256923.1 & Horse_Hsp70_R & ATCACCTCCTGGCATTTGTC & & 57.3 \\
NM_001163856.1 & Horse_GAPDH_F & CGCTTCCCTTCCGCACTGCT & 229 & 63.4 \\
NM_001163856.1 & Horse_GAPDH_R & CCCGTGCTCGGCCTTGACTG & & 65.5 \\
\hline
\end{tabular}




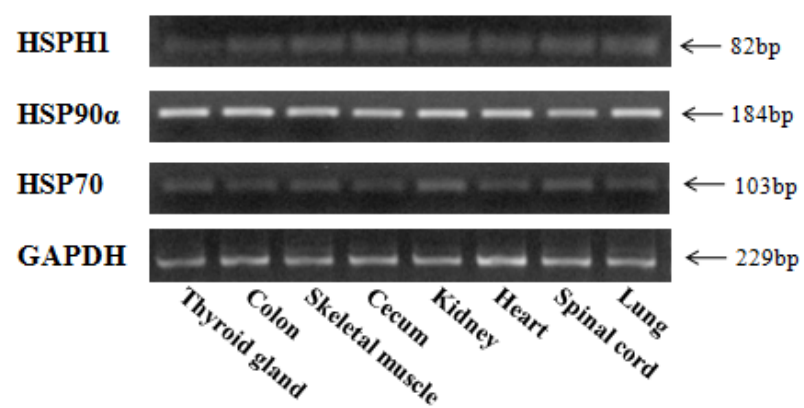

Fig. 1. Expression of the horse Hsp genes determined by RTPCR in a variety of thoroughbred horse (Equus caballus) tissues.

$60^{\circ} \mathrm{C}$ 에서 10 초간 annealing, $72^{\circ} \mathrm{C}$ 에서 30 초간 extension을 50 회 반복하였다. 모든 측정은 시료 당 3 반복을 하였고, 상대 정량법은 $2^{-\Delta \Delta \mathrm{Ct}} \operatorname{method}$ 를 사용하였다[20]. 타겟 유전자들의 상대발현은 GAPDH (glyceraldehyde-3-phosphate dehydrogenase)를 이용하여 계산하였다.

\section{결과 및 고찰}

말 조직에서 RT-PCR을 이용한 발현량 분석

$H s p H 1, H s p 90 a, H s p 70$ 의 말 조직 별 발현 양상을 확인하기
위하여 3 두의 제주마 조직을 이용하여 RT-PCR을 수행한 결 과 사용된 8 개의 조직(갑상선, 결장, 골격근, 맹장, 신장, 심장, 척수, 폐) 모두에서 발현을 확인할 수 있었다(Fig. 1). 세 유전자 가 8 개의 조직에서 존재한다는 것은 $H s p H 1, H s p 90 a, H s p 70$ 이 조직특이적인 유전자들에 반해, 다양한 역할을 담당한다는 것 을 뜻한다.

\section{운동 후 열충격 단백질 유전자의 발현량 분석}

경주마 혈액에서 시간 별(운동 전, 30 분, 60 분, 90 분, 120 분)로 $H_{s p H 1} H_{s p 90 a, H s p 70}$ 유전자의 상대적인 발현을 분석 하기 위해 real-time qPCR을 이용하여 상대발현을 확인하였 다(Fig. 2B). 그 결과, $H s p H 1$ 의 경우 운동 전에 비해 운동 30 분 후에 발현이 증가하였고, 이후 감소하여 발현량이 유지됨 을 확인하였다. 이는 Table 1에 제시된 in sillico data와 일치함 을 검증하였다. Hsp90a의 경우 운동 30 분까지 발현이 증가하 였으나, 운동 60 분과 90 분 후에 점차 감소하다 다시 운동 120 분 후에서는 발현이 증가하는 경향을 보였다. 특이적인 것은 운동 전에 비해 운동 후 모든 시간별에서 발현이 증가함을 나타냈다. $H s p 70$ 의 경우 $H S P H 1$ 과 마찬가지로 운동 30 분 후 발현이 높아졌다가 이후 감소하여 유지되는 양상을 나타내었 다. 이러한 결과들은 운동이라는 현상에 의해 생리적인 현상 이 변화함에 따라 혈액과 근육에서의 $H_{s p H}$ 과 $H s p 90 a, H s p 70$

A

(a) HSPH1

(b) HSP90a

(c) HSP70

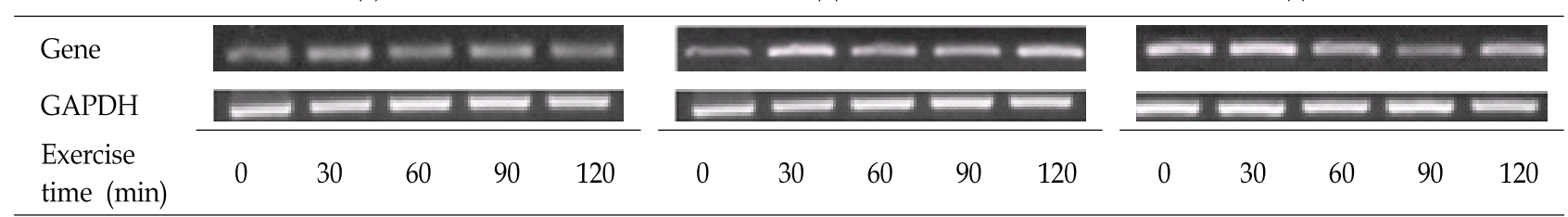

(a) Arbtrary unit

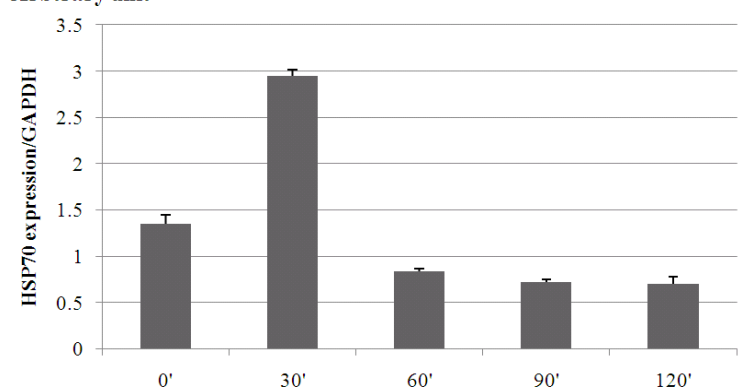

(c) Arbitrary unit

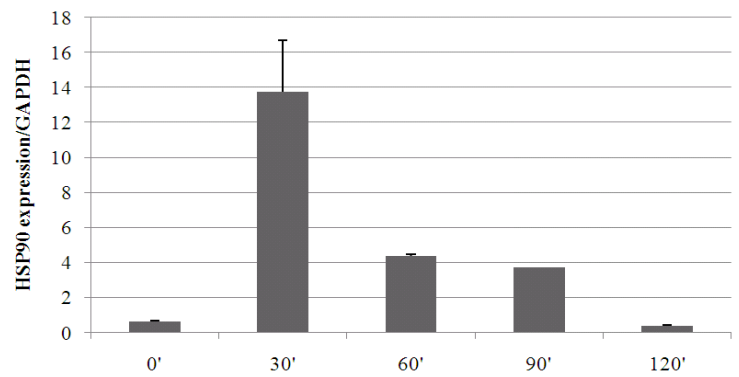

(b) Arbtrary unit

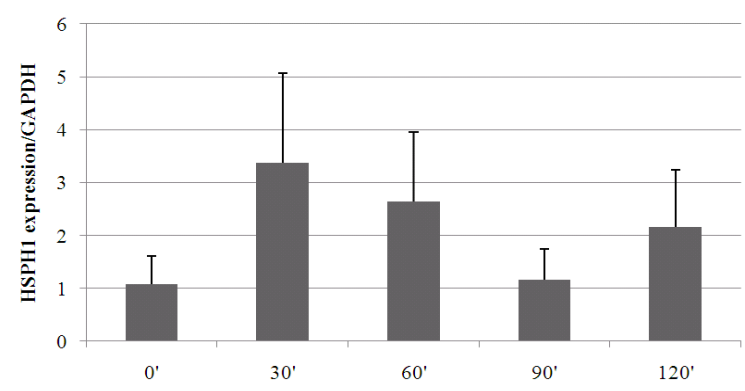

Fig. 2. Relative expression of Hsp genes determined by realtime qPCR in horse before and after exercise $(30,60$, 90 and 120 min). (a). HspH1, (b). Hsp90a, (c). Hsp70, $0^{\prime}$ : before exercise, $30^{\prime}$ : after $30 \mathrm{~min}, 60^{\prime}$ : after $60 \mathrm{~min}$, 90': after 90 minutes, $120^{\prime}$ : after $120 \mathrm{~min}$. 
의 발현에 영향을 미친다는 것으로 사료된다. 운동에 의해 세 포 내 스트레스가 증가하는데 대표적인 현상으로 단백질의 변성과 접힘 과정의 오류를 유발할 수 있는 ATP 부족현상, 활성 산소의 생성에 의한 산화적 환경, 세포 내 $\mathrm{pH}$ 감소 등을 들 수 있다[26]. Hsp70의 경우 이를 뒷받침 할 수 있는 연구들 이 많이 보고되었는데, 구조적 특징을 보면 말 뿐만 아니라 대부분의 다른 종에서도 인트론이 없는 단일 엑손 구조이다. 이러한 구조적 특징은 스트레스에 빠른 대응을 하기 위한 것 으로 알려져 있다[1].

또한, rat에서 강도 높은 운동을 실시한 결과, 골격근과 림프 구, 비장에서 $H s p 70$ 의 발현이 증가됨을 확인하였다[22]. 이와 비슷하게 다양한 종의 동물 실험을 통하여 급격한 운동이 골 격근과 심장, 신장, 간에서의 $H s p 70$ 의 발현을 유도함을 관찰하 였다 $[17,21,32]$. 또한 사람을 대상으로 한 운동 실험에서도 $H s p 70$ 의 합성이 증가됨을 확인 할 수 있었다[36]. 운동에 따른 $\mathrm{Hsp}$ 의 발현량 증가 외에도 운동의 강도와 $\mathrm{Hsp}$ 의 발현량 간의 관계에 대한 연구 또한 많이 진행되어 왔다. 한 연구결과에 따르면, 운동의 강도와 $\mathrm{Hsp}$ 의 발현량이 양의 상관관계를 보임 으로써 열 충격 반응의 정도가 운동의 강도와 관련이 있음이 보고되었다[23]. 또한, 사람의 경우 운동 지속시간이 길어질수 록 혈장 내 $H s p 70$ 단백질의 양이 증가됨이 보고되었다[9]. 이 와 비슷하게 $H s p 70$ 을 real-time qPCR을 수행하여 골격근에서 확인한 결과 지속적으로 3 시간의 운동 시 mRNA의 발현량이 크게 증가함이 보고되었다[8]. 다양한 종에서 운동강도 및 지 속시간에 의해 열충격 단백질 유전자의 발현이 증가함은 운동 에 의한 스트레스에 의해 열충격 단백질의 발현 조절 메커니 즘 및 증가된 열충격 단백질의 기이 보존적임을 시사한다. 또 한, 개체특이성을 고려하여 열충격 단백질 유전자에 대한 운 동에 따른 메커니즘 연구를 수행하는 것이 바람직함으로 예상 된다.

또한, oxidative stress, hypoxia state, energy의 부족 등이 운동 후 열충격 단백질의 발현을 증가 시킨다는 연구는 있다 $[16,18,28]$. 외부자극에 의한 열충격 단백질의 발현이 조절됨 은 보고되었으나, 아직까지 어떠한 메커니즘에 의해 운동 후 열충격 단백질의 발현을 유도하는지는 밝혀지지 않고 있다. 때문에, 열충격 단백질의 발현이 어떠한 신호전달 및 메커니즘 에 의해 차이가 발생하는지에 대한 추가적인 연구가 필요하다. 이밖에 혈액을 대상으로 운동 전, 후 열충격 단백질의 발현 량 비교에 대한 연구도 지속적으로 이루어져 왔다. 혈액은 조 직에 비해 상대적으로 채취하기도 용이할 뿐만 아니라 여러 가지 임상진단에 널리 활용될 수 있는 장점이 있다. 혈액에 존재하는 혈구 가운데 핵을 가진 세포는 백혈구로 monocyte, neutrophil, eosinophil, basophil, B lymphocyte, T lymphocyte 등이 있다. 혈액 내 운동에 의해 발현이 변화하는 유전자 는 이러한 백혈구의 핵에 존재할 가능성이 크다. Hsp70과 함께 $H s p 27, H s p 60$ 의 발현이 운동 후 백혈구에서 현저하게 증가됨
이 보고되었는데, 흥미로운 점은 운동 전 상태에서의 $H s p 70$ 의 발현량이 해당 개체의 훈련의 정도에 따라 유의적인 차이가 난다는 것이다[7]. 이를 뒷받침하는 연구로 rat 골격근의 실험 을 통해 규칙적인 훈련 시, 산소에 노출되는 거의 모든 세포에 서 항산화 방어기작을 담당하는 superoxide dismutase (SOD) 의 활성이 촉진됨을 확인하였다[5]. 이와 비슷하게 훈련의 정 도에 따른 antioxidant system의 활성을 확인한 연구들도 많이 보고되어 있다[31].

아울러 사람을 대상으로 1 시간 동안 treadmill 운동을 한 결과, 운동 후 혈액 속 백혈구에서 $H s p 70, H_{s p 90}$ 의 발현량이 증가함을 보고한 연구결과가 있다[33]. 이러한 연구 결과들을 바탕으로 훈련에 따른 antioxidant system과 열충격 단백질 발현량의 관련성을 추측해 볼 수 있다. 따라서 모델동물로써 의 가능성과 훈련 강도에 따른 맞춤형 운동의 지표가 될 수 있음을 시사한다. 하지만, 일반 말과는 다르게 지속적인 훈련 을 받는 경주마의 경우 열충격 단백질의 발현과 antioxidant system에 관계하는 유전자들과의 관계에 대한 연구 또한 선행 적으로 필요함을 시사한다.

\section{감사의 글}

본 논문은 농촌진흥청 차세 대 바이오그린21사업(과제번 호: PJ008106)의 자원에 의해 이루어진 것임.

\section{References}

1. Barbara, W. U., Hunt, C. and Morimoto, R. 1985. Structure and expression of the human gene encoding major heat shock protein HSP70. Mol Cell Biol 5, 330.

2. Beere, H. M., Wolf, B. B., Cain, K., Mosser, D. D., Mahboubi, A., Kuwana, T., Tailor, P., Morimoto, R. I., Cohen, G. M. and Green, D. R. 2000. Heat-shock protein 70 inhibits apoptosis by preventing recruitment of procaspase- 9 to the Apaf-1 apoptosome. Nature Cell Biol 2, 469-475.

3. Beckmann, R. P., Mizzen, L. E. and Welch, W. J. 1990. Interaction of Hsp 70 with newly synthesized proteins: implications for protein folding and assembly. Science 248, 850-854.

4. Cornelussen, R., Spiering, W., Webers, J. H., De Bruin, L. G., Reneman, R. S., Van der Vusse, G. and Snoeckx, L. H. 1994. Heat shock improves ischemic tolerance of hypertrophied rat hearts. Am J Physiol 267, H1941-H1947.

5. Criswell, D., Powers, S., Dodd, S., Lawler, J., Edwards, W., Renshler, K. and Grinton, S. 1993. High intensity training-induced changes in skeletal muscle antioxidant enzyme activity. Med Sci Sports Exerc 25, 1135-1140.

6. Donati, Y. R., Slosman, D. O. and Polla, B. S. 1990. Oxidative injury and the heat shock response. Biochem Pharmacol 40, 2571-2577.

7. Ehrenbach, E., Passek, F., Niess, A., Pohla, H., Weinstock, C., Hans Herrmann, D. and Northoff, H. 2000. Hsp ex- 
pression in human leukocytes is modulated by endurance exercise. Med Sci Sports Exerc 32, 592-600.

8. Febbraio, M. A. and Koukoulas, I. 2000. Hsp72 gene expression progressively increases in human skeletal muscle during prolonged, exhaustive exercise. J Appl Physiol 89, 1055-1060.

9. Fehrenbach, E., Niess, A. M., Voelker, K., Northoff, H. and Mooren, F. C. 2005. Exercise intensity and duration affect blood soluble Hsp72. Int J Sports Med 26, 552-557.

10. Hammond, G. L., Lai, Y. K. and Markert, C. L. 1982. Diverse forms of stress lead to new patterns of gene expression through a common and essential metabolic pathway. Proc Natl Acad Sci USA 79, 3485-3488.

11. Hartl, F. U. 1996. Molecular chaperones in cellular protein folding. Nature 381, 571-580.

12. Hatayama, T., Takigawa, T., Takeuchi, S. and Shiota, K. 1997. Characteristic expression of high molecular mass heat shock protein Hsp105 during mouse embryo development. Cell Struc Funct 22, 517.

13. Hatayama, T., Yasuda, K. and Yasuda, K. 1998. Association of Hsp105 with HSC70 in high molecular mass complexes in mouse FM3A cells. Biochem Biophys Res Commun 248, 395-401.

14. Hightower, L. E. 1991. Heat shock, stress proteins, chaperones, and proteotoxicity. Cell 66, 191-197.

15. Hunt, C. and Morimoto, R. I. 1985. Conserved features of eukaryotic Hsp70 genes revealed by comparison with the nucleotide sequence of human Hsp70. Proc Natl Acad SCi 82, 6455-6459.

16. Kabakov, A. E. and Gabai, V. L. 1997. Heat shock proteins and the regulation of heat shock gene expression in eukaryotes. pp. 1-19. Springer US.

17. Kregel, K. C. and Moseley, P. L. 1996. Differential effects of exercise and heat stress on liver Hsp70 accumulation with aging. J Appl Physiol 80, 547-551.

18. Kukreja, R. C., Kontos, M. C., Loesser, K. E., Batra, S. K., Qian, Y. Z., Gbur, C. J. and Hess, M. L. 1994. Oxidant stress increases heat shock protein $70 \mathrm{mRNA}$ in isolated perfused rat heart. Am J Physiol 267, H2213-H2219.

19. Laszlo, A. 1988. Evidence for two states of thermotolerance in mammalian cells. Int J Hyperthermia 4, 513-526.

20. Livak, K. J. and Schmittgen, T. D. 2001. Analysis of relative gene expression data using real-time quantitative PCR and the 2- $\Delta \Delta$ CT method. Methods 25, 402-408.

21. Locke, M. and Noble, E. G. 1995. Stress proteins: the exercise response. Can J Appl Physiol 20, 155-167.

22. Locke, M., Noble, E. G. and Atkinson, B. G. 1990. Exercise mammals synthesize stress proteins. Am J Physiol 258, C723-C729.

23. Milne, K. J. and Noble, E. G. 2002. Exercise-induced elevation of Hsp70 is intensity dependent. J Appl Physiol 93,
561-568.

24. Minowada, G. and Welch, W. J. 1995. Clinical implications of the stress response. J Clin Invest 95, 3.

25. Moseley, P. L. 1997. Heat shock proteins and heat adaptation of the whole organism. J Appl Physiol 83, 1413-1417.

26. Noble, E. G. 2002. Heat shock proteins and their induction with exercise. pp. 43-78. In: Locke, M. and Noble, E. G. (eds.), Exercise and stress response: the role of stress proteins. Boca Raton

27. Park, K. D., Park, J., Ko, J., Kim, B. C., Kim, H. S., Ahn, K. and Cho, B. W. 2012. Whole transcriptome analyses of six thoroughbred horses before and after exercise using RNA-Seq. BMC Genomics 13, 473.

28. Patel, B., Khaliq, A., Jarvis-Evans, J., Boulton, M., Arrol, S., Mackness, M. and McLeod, D. 1995. Hypoxia induces Hsp 70 gene expression in human hepatoma (HEP G2) cells. Biochem Mol Biol Int 36, 907-912.

29. Ritossa, F. 1962. A new puffing pattern induced by temperature shock and DNP in Drosophila. Experientia 18, 571-573.

30. Pratt, W. B. 1987. Transformation of glucocorticoid and progesterone receptors to the DNA-binding state. J Cell Biochem $35,51-68$.

31. Robertson, J., Maughan, R., Duthie, G. and Morrice, P. 1991. Increased blood antiocidant systems of runners in response to training load. Clin Sci 80, 611-618.

32. Salo, D. C., Donovan, C. M. and Davies, K. J. 1991. Hsp70 and other possible heat shock or oxidative stress proteins are induced in skeletal muscle, heart, and liver during exercise. Free Radic Biol Med 11, 239-246.

33. Shastry, S., Toft, D. O. and Joyner, M. J. 2002. Hsp70 and Hsp90 expression in leucocytes after exercise in moderately trained humans. Acta Physiogica Scandinavica 175, 139-146.

34. Sorger, P. K. and Pelham, H. R. 1987. Cloning and expression of a gene encoding hsc73, the major Hsp70-like protein in unstressed rat cells. EMBO J 6, 993.

35. Subjeck, J. R. and Shyy, T. T. 1986. Stress protein systems of mammalian cells. Am J Physiol 250, C1-C17.

36. Thompson, H. S., Clarkson, P. M. and Scordilis, S. P. 2002. The repeated bout effect and heat shock proteins: intramuscular Hsp27 and Hsp70 expression following two bouts of accentric exercise in humans. Acta Physiol Scand 174, 47-56.

37. Wegele, H., Müller, L. and Buchner, J. 2004. Hsp70 and Hsp90 - a relay team for protein folding. Rev Physiol Biochem Pharmacol 151, 1-44.

38. Welch, W. J. and Feramisco, J. R. 1984. Nuclear and nucleolar localization of the 72,000-dalton heat shock protein in heat-shocked mammalian cells. J Biol Chem 259, 4501-4513.

39. Yamamoto, H., Shi, X. and Nuttall, A. L. 2009. The influence of loud sound stress on expression of osmotic stress protein 94 in the murine inner ear. Neuroscience 158, 1691-1698. 


\section{초록 : 말의 열충격 단백질(heat shock proteins)의 특성 구명과 운동 후 유전자의 발현 분석}

조현우 ${ }^{1}$ 박정웅 ${ }^{1}$ 최재영 ${ }^{1}$ 시바 쿠마르 ${ }^{2}$. 김남영 ${ }^{3}$ 신택순 ${ }^{1}$. 조성근 ${ }^{1}$ 김병우 ${ }^{1}$ 조병욱 ${ }^{1 *}$

( ${ }^{1}$ 부산대학교 생명자원과학대학 동물생명자원과학과, ${ }^{2}$ 부산대학교 생명자원과학대학 바이오환경에너지학 과, ${ }^{3}$ 농촌진흥청 국립축산연구소 난지축산시험장)

본 연구의 목적은 말의 열충격 단백질 유전자의 특성을 구명하고 말의 각 조직과 운동 전과 후 혈액에서 열충 격 단백질 유전자의 발현량을 분석함에 있다. 이전의 연구를 통해, 대표적인 경주마인 더러브렛의 혈액과 골격근 에서 운동 전, 후 RNA-sequencing을 통해 차등발현유전자 분석을 실시하고, 본 연구를 위해 운동 전과 후에 차등 발현된 유전자 중, 열충격 단백질 유전자(HspH1, Hsp90a, Hsp70)를 선택하였다. 세 개의 열충격 단백질 유전자는 각각의 혈액이나 근육에서 운동 전에 비해 후에 발현이 증가된 것으로 확인됐다. 본 연구팀은 선정된 유전자에 대한 검증과 분석을 위해, 말의 조직별 RT-PCR 분석과 운동시간별 백혈구에서 real time qPCR 분석을 실시하였 다. 그 결과 말의 각 조직(갑상선, 결장, 골격근, 맹장, 신장, 심장, 척수, 폐)에서 세 개의 열충격 단백질 유전자 mRNA가 모두 존재함을 알 수 있었다. 또한, 말의 운동 시간 별 혈액에서 mRNA를 추출하여 열충격 단백질의 운동 시간에 따른 발현 양상 분석을 실시한 결과, 운동 전에 비해 운동 120 분 후 열충격 단백질 유전자의 발현량이 증가함을 확인하였다. 이러한 결과는 인간과 다른 동물 실험의 결과와 일치하며, 열충격 단백질 유전자 전사 조절 기작이 종간에 보존이 되어왔음을 시사한다. 또한, 운동에 따른 열충격 단백질 유전자의 발현 양상과 운동 수행 및 회복 기작간의 상관관계에 대한 추가적인 연구가 필요함을 제안하는 바이다. 